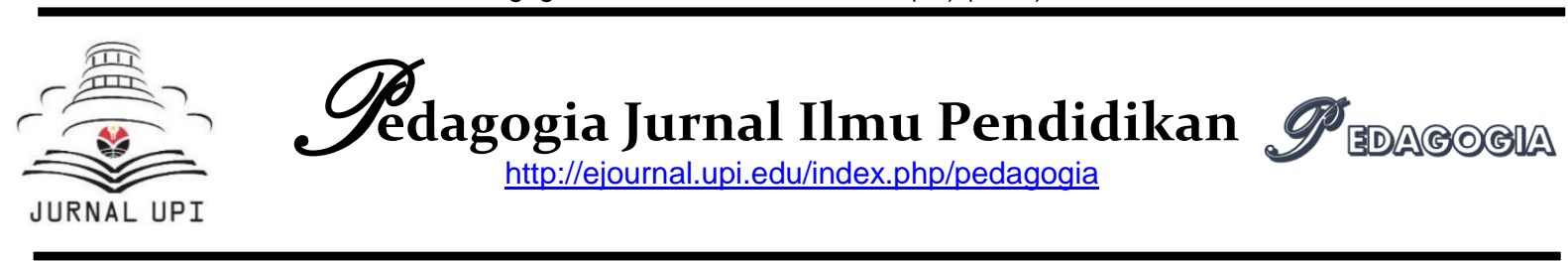

\title{
Active Learning System Implementation Using ETH Method to Enhance Student Oral Activities
}

\author{
Imanuel Adhitya Wulanata Chrismastianto \\ Rani Elisa Purba \\ Prodi Pendidikan Ekonomi \\ Fakultas Ilmu Pendidikan \\ Universitas Pelita Harapan, Tangerang \\ imanuel.wulanata@uph.edu
}

\begin{abstract}
A b s t r a c t
This research was conducted to address students' activities in learning Biology by applying the method Everyone is a Teacher Here (ETH). This research aims to study the ETH method that can enhance students' oral activity in learning. The research method used is the Classroom Action Research (CAR) method with the Kemmis and Mc Taggart models that last for two cycles. Research activities carried out in class X-A SDH Holland Village Manado. Data collection instruments used were student observation sheets, student questionnaire sheets, and student interview guidelines. Everyone is a Teacher Here (ETH) who can enhance students' verbal activities. This can be seen based on observations on each indicator that is $34.38 \%, 48.44 \%, 48.96 \%$, and $51.04 \%$, while in the second cycle $56.25 \%, 57.82 \%, 55.73 \%$ and $51.04 \%$. Everyone is a teacher here (ETH) by following each stage and discussing students who act as teachers who can remind the oral activities of class X-A students in Biology.
\end{abstract}

\begin{tabular}{|c|}
\hline Article Info \\
\hline $\begin{array}{l}\text { Naskah Diterima : } \\
\text { 2019-11-21 }\end{array}$ \\
\hline $\begin{array}{l}\text { Naskah Direvisi: } \\
2020-02-11\end{array}$ \\
\hline $\begin{array}{l}\text { Naskah Disetujui: } \\
\text { 2020-03-13 }\end{array}$ \\
\hline
\end{tabular}

Keywords : Oral Activity, Active Learning, Everyone Is A Teacher Here (ETH), Student

\begin{abstract}
A b s trak
Penelitian ini dilakukan untuk menyikapi permasalahan aktivitas siswa pada pembelajaran Biologi dengan menerapkan metode Everyone is a Teacher Here (ETH). Penelitian ini bertujuan untuk mengetahui bahwa metode ETH dapat meningkatkan aktivitas lisan siswa dalam pembelajaran Biologi khususnya pada aktivitas membagikan suatu prinsip atau fakta, mengajukan pertanyaan, mengajukan jawaban dan kontribusi dalam kelompok. Metode penelitian yang digunakan adalah metode Penelitian Tindakan Kelas (PTK) dengan model Kemmis dan Mc Taggart yang berlangsung selama dua siklus. Kegiatan penelitian dilaksanakan di kelas X-A SDH Holland Village Manado. Instrumen pengumpulan data yang digunakan yaitu lembar observasi siswa, lembar angket siswa, dan pedoman wawancara siswa. Hasil penelitian menunjukkan bahwa penerapan sistem pembelajaran aktif dengan metode Everyone is a Teacher Here (ETH) dapat meningkatkan aktivitas lisan siswa. Hal tersebut dapat dilihat berdasarkan hasil observasi pada setiap indikator yaitu $34,38 \%$, $48,44 \%$, 48,96\%, dan 51,04\%, sedangkan pada siklus dua 56,25\%, 57,82\%, 55,73\%, dan $51,04 \%$. Hasil penelitian juga menunjukkan bahwa penerapan metode Everyone is a Teacher Here (ETH) dengan mengikuti setiap tahapan dan mengawasi siswa menjalankan peran sebagai seorang guru dapat meningkatkan aktivitas lisan siswa kelas X-A pada mata pelajaran Biologi.
\end{abstract}

Kata kunci: Aktivitas Lisan, Pembelajaran Aktif, Everyone Is a Teacher Here (ETH), Siswa 


\section{A. INTRODUCTION}

Currently the government hopes about Curriculum 2013 implementation can run with a student-centered learning model and requires students to be active in learning (Kemendikbud, 2014). Diedrich (2015) was classified the learning activities of students in eight groups, as follows: a). Visual activities such as reading, watching experiments, demonstrations, exhibitions, and watching others work or play; b). Oral activities as posted a fact, connecting such events, ask questions, give advice, express opinions, interviews, discussions, and interruptions; c). Listening activities such dictations, conversations, discussions, music, speeches, and so forth; d). Writing activities such as story writing essays, reports, tests, questionnaires, copying; e). Drawing activities such as drawing, making graphs, maps, diagram, patterns, and so on; f). Motor activities like to experiment, make the construction, the model playing, gardening, raise animals, and so on; g). Mental activities as contemplate, remember, solve problems, analyze, look at relationships, decision-making, and so, and h). Emotional activities interested, bored, excited, bold, calm, nervous, and so on (Winarso, 2016). Oral activity of students in the classroom is a sign that students have carried out acquiring knowledge process (Adhani, 2014). This shows that the students' verbal activities in the classroom have a close relationship with students' cognitive learning outcomes.

Speaking is the productive skill in the oral mode. It, like the other skills, is more complicated than it seems at first and involves more than just pronouncing words (Hossain, 2015). Speaking skill has been very important to the success of human beings. The significance of speaking skill is observed in the daily activities of persons (Leong, 2017). One community owned by students to develop the ability of oral activities (speaking skill) is in the classroom by conducting educational or reciprocal interactions between class community members. Humans are designed by God as social beings who can carry out social interactions, include the ability of oral activities. The opinion above was confirmed by Whelchel (Wibawanta, 2017), by stating that humans at the beginning of creation were designed in four healthy relationships, one of which was a relationship with another person based on the relationship of the Triune God. The sentence "let us make mankind, etc." In Genesis 1:26 from the Bible, shows the existence of God as a God alliance and that fellowship is then known as trinity (Hoekema, 2015). This is the basis for humans to interact, so that the relationships ability is one manifestation of human likeness with the Triune God.

Based on introduction above, so this research aims to study the ETH method that can enhance students' oral activity in learning. Hopefully, through this research we can get the idea to implementing the active learning system to enhance student oral activities in our classroom. This research in line with the statement of Nadiem Makariem, Indonesian Education and Culture Minister, said it is reflected in teachers or lecturers who constantly grow their knowledge to improve the learning activities in classes or outside the confines of classes and involve their students to partake in external projects that will elevate the experience (Nugraha, 2019).

\section{B. LITERATURE REVIEW \\ 1. Active Learning System}

Active learning is a learning that is designed to achieve independent learning by maximizing all potential learners (Siregar \& Nara, 2010). Based on its implementation, The National Survey of Student Engagement (NSSE) and the Australasian Survey of Student Engagement (AUSSE) provides a very simple definition: active learning involves 'students' efforts to actively construct their knowledge." This definition is supplemented by the items that the AUSSE uses to measure active learning: working with other students on projects during class; making a presentation; asking questions or contributing to discussions; participating in a community-based project as part of a course; working with other students outside of class on assignments; discussing ideas from a course with others outside of class; tutoring peers (Brame, 2016). Active learning requires students to intellectually engage with the content using critical thinking or higher level of thinking such as analysis or synthesis (Edwards, 2015). In active learning interactions, the teacher functions more as a facilitator who 
coaches, mediates, prompts, and helps students develop and assess their understanding, and thereby their learning (Bada \& Olusegun, 2015). Basically, the active nature possessed by students is one consequence of the fact that humans are created as the image and likeness of God. Reinforcing this opinion Wibawanta \& Hendra (2017), said that human beings are creations in which there is a nature that causes humans to actively search for something to meet their inner needs.

\section{Everyone Is A Teacher Here (ETH) Method}

Everyone is a Teacher Here (ETH) is one of the methods in active learning that can be used to get class participation as a whole or individually (Suprijono, 2009). Literally the meaning of Everyone is a Teacher Here is everyone is a teacher here in the classroom's activities. In accordance with the literal understanding above the Everyone is a Teacher Here (ETH) method is a method that provides opportunities and responsibilities to become a teacher or teacher for other students (Siberman, 2009). The Everyone is a Teacher Here (ETH) method has the following advantages: 1) students have the courage to express their opinions through self-written answers; 2) students are able to express opinions through writing; 3 ) students are able to provide input and refute the opinions of other friends; and 4) students are trained to make conclusions from the problems studied (Yanti, 2017). Silberman (2009) suggests the weaknesses of the Everyone is a Teacher Here (ETH) method, which are as follows: 1) the questions asked by students are not in accordance with the learning objectives; 2) takes a long time to discuss one material and answer all questions in a large class; and 3) in some questions it was found that students were unable to answer questions.

The Everyone is a Teacher Here (ETH) method is implemented with the following procedure: 1) distributing index cards to each student and asking students to write questions about the subject matter being studied in class; 2) each card that has been written questions collected and then stirred to be randomly distributed to all students. At this stage, students will be given the opportunity to read the questions obtained and think of the answers to these questions; 3) volunteer students will be asked to submit answers to questions obtained; after the answers are submitted, other students are given the opportunity to provide additional or refutation; 4 ) if there is enough time the activity will resume by reading the questions of the next volunteer (Siberman, 2009).

The application of the Everyone is a Teacher Here (ETH) method which consists of the five stages above is described by Zaini (in Gimin, Haryana, \& Kartikowati, 2016) into eight stages of implementation consisting as follows: 1 ) distributing a piece of paper to students; 2) students will write one question on a paper about the material they have learned; 3) papers containing questions will then be collected and distributed randomly to all students; 4) the teacher makes sure that none of the students receive their own paper; 5) students are asked to think of answers to questions obtained; 6) volunteer students are given the opportunity to read questions and submit answers; 7) other students are given the opportunity to add the answers that have been submitted; 8) the activity is continued with the next volunteer and if there is no next volunteer, the teacher will randomly appoint students to submit answers to the questions obtained.

Everyone is a Teacher Here (ETH) method implementation the teacher acts as a facilitator while other students are given the opportunity to become teachers of other students (Suprijono, 2009). As a facilitator, the teacher has several tasks which include: 1) the teacher must help students and provide psychological, pedagogical and academic facilities to build student skills; 2) the teacher must draw up a learning plan according to the needs and interests of students and be able to accommodate a variety of student learning styles; and 3 ) the teacher as a facilitator must be able to evaluate the learning process and make the evaluation results as an improvement material for the next learning (Warsono \& Hariyanto, 2012).

\section{Student Oral Activity}

Oral activities are all activities that involve the ability to speak and are intended to convey information (Hamalik, 2010). The Curriculum 2013 classifies oral activity in the 
realm of response that shows how students react to an event or is called a stimulus by the behavior. The reaction of students responding to an event is shown by several operational verbs as follows: answering, helping, obeying, fulfilling, agreeing, discussing, doing, presenting, presenting, reporting, telling, writing, interpreting, completing and practicing (Kosasih, 2016). In summary the indicators of students' verbal activities in class can be seen in table 1 below :

Table 1

Indicators of Oral Activity and Derivatives

\begin{tabular}{ll}
\hline \multicolumn{1}{c}{ Indicator } & \multicolumn{1}{c}{ Statements } \\
\hline $\begin{array}{l}\text { Present a certain fact or } \\
\text { principle }\end{array}$ & $\begin{array}{l}\text { Students give examples of facts or principles relating to the } \\
\text { material being studied. }\end{array}$ \\
\hline Asking question & $\begin{array}{l}\text { 1. Students give questions to the teacher or other students. } \\
\text { 2. Asking questions or comments / rebuttal when the teacher or } \\
\text { other students are conveying information. }\end{array}$ \\
\hline Answer the question & $\begin{array}{l}\text { 3. Being able to give correct and correct answers when the } \\
\text { teacher or other students ask questions to all class } \\
\text { members. Appointed by the teacher or his own initiative. }\end{array}$ \\
& $\begin{array}{l}\text { 4. Able to give answers correctly, precisely and not stammer } \\
\text { when the teacher gives specific questions to student. }\end{array}$ \\
\hline $\begin{array}{l}\text { Contribute to group } \\
\text { discussions }\end{array}$ & $\begin{array}{l}\text { 5. Students actively discuss and express opinions according to } \\
\text { the topic of learning in groups. }\end{array}$ \\
6. Students give a response to something the issue or problem \\
being discussed.
\end{tabular}

Source: Adapted from Hamalik (2010, p. 172)

The student oral activity in the classroom is important to be improved to enhance communication (interaction) between class communities, because the communication that is expected to occur in the classroom is multi directional communication (Sumiati \& Asra, 2008). Interactions that are expected to occur in the classroom, not only fulfill the social needs of humans to communicate, but these interactions can create a good and beautiful community so that the Triune God community can shine through interactions that occur in the classroom. This can be realized by making the class a community of hope, service, reconciliation, mutual support, generosity, and worship (Smith, 2014).

\section{RESEARCH METHOD}

The research conducted was a Classroom Action Research (CAR). Wiriaatmadja (2009) briefly explains that
CAR is an improvement effort on the learning practices undertaken by teachers where teachers can see firsthand the influence of the effort. In this study, researcher used Spiral Model of CAR from Kemmis and Taggart. Kemmis and Taggart explains that the CAR can be done in four steps, which are (1) planning, (2) acting, (3) observing, and (4) reflecting (Oktapratama, Chrismastianto \& Hidayat, 2019). The purpose of CAR is according to Trianto (2011) is to solve problems, improve conditions, develop and improve the quality of learning. The CAR design chosen by the researcher was the CAR design of Kemmis and Mc Taggart models, which used four stages and was carried out repeatedly (spirally). The four stages are planning, acting, observing, reflecting, and replanning which is the basis for a square off problem solving (Trianto, 2011). The four stages are carried out in two cycles. The following is a picture of the CAR cycle used in this research: 


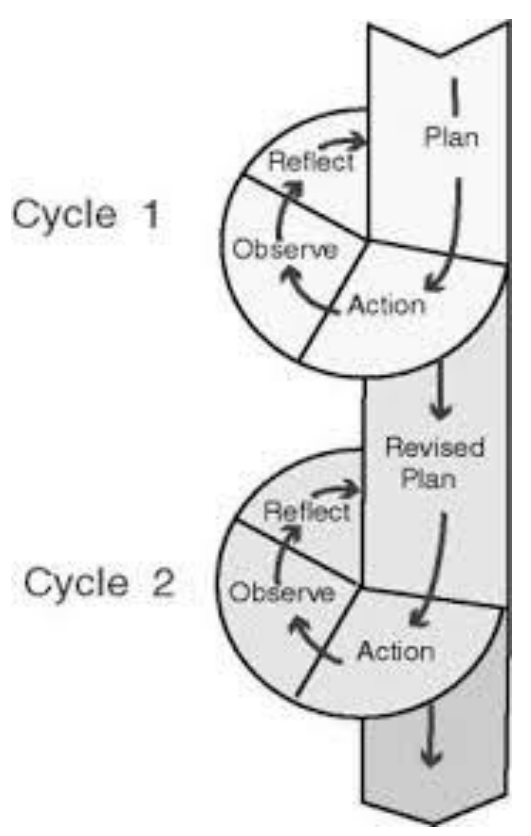

Picture 1

CAR design of Kemmis and Mc Taggart models

This research took place in class $X-A$ Dian Harapan Holland Village Manado School on Biology. In this study, researchers took 8 out of 14 students as research subjects. Students who are the subjects of research are students who have a low level of oral activity. This is based on the results of observations, questionnaires and interviews conducted during the pre cycle. Subjects consisted of six female students and two male students. This research took place from October 24 to October 31, 2017.

The instrument used to measure the level of students' oral activities was based on data triangulation techniques using observation sheet instruments, questionnaire sheets and interview guidelines while the application of ETHmethod was based on triangulation of sources using observation sheets filled by three observers. The researcher took the $70 \%$ indicator completeness criteria which stated that most subjects had achieved the expected indicator provisions (Kirkpatrick \& Kirkpatrick, 2008, p. 162). The criteria for applying Everyone is a Teacher Here (ETH) method in this study is $70 \%$ which states that each stage of the method has been implemented well (Tampubolon, 2014, p. 35).

In this study, the data collected is qualitative data and quantitative data will be converted into qualitative. Qualitative data is data in the form of information that gives an overview of the level of attitude to be measured while quantitative data is data that will be analyzed using descriptive statistics (Arikunto, Suhardjono, \& Supardi, 2012). Data analysis work involves three steps, namely: preparation, tabulation and application of data in accordance with the research approach (Arikunto, 2010). The cycle will continue if the value of each indicator does not reach the specified criteria, which is at least $70 \%$.

\section{DISCUSSION AND RESULT \\ 1. CAR Cycle 1}

Based on data processing results in cycle 1, it shows that Everyone is a Teacher Here $(E T H)$ method implementation can enhance students' oral activities which are shown based on the percentage of indicators obtained using each instrument. The observation sheet instrument showed an enhance in oral activity, even though the level of improvement shown did not reach the specified completeness criteria. The enhance in the percentage of each indicator is measured through observation using the observation sheet on each indicator that is equal to $34.38 \%, 48.44 \%, 48.96 \%$, and $51.04 \%$. The ALS-1 indicator is an oral activity which is demonstrated through the activity of sharing certain facts or principles 
in the classroom. Oral activity of students in the classroom has a close relationship with student learning outcomes cognitively. This is in line with the opinion of Adhani (2014), which states that oral activity is evidence that students have obtained information in learning. Albert Bandura in social psychology theory revealed a close relationship between behavior, cognitive and environment (Santrock, 2007). The close relationship can be defined that the three sections above affect each other and have a reciprocal relationship, meaning that a person's behavior such as oral activity is influenced by one's cognitive and vice versa one's cognitive ability is influenced by the level of oral activity.

\section{CAR Cycle 2}

Based on data processing results in cycle 2 , in the observation instrument it is known that the enhance in the ALS-2 indicator has not yet reached the specified completeness limit while the questionnaire sheet instrument used shows an increase that has reached the specified completeness limit. This can occur because of differences in the nature of the instruments used to measure the increase in oral activity. The results of the observation sheet displayed were the observations of three observers while the questionnaire data displayed was data filled out by students themselves as respondents. Some things that are needed by someone when asking questions in class are self-confidence, high curiosity, desire to learn, and the ability to communicate the things that want to be asked. Student backgrounds that are influenced by the past, family and environment have an impact that shapes the personality of students.

Both instruments show an enhance in the percentage of ALS-3 indicators, but the indicated improvement does not reach the specified completeness limit. ALS-3 indicators are shown through activities providing answers to the questions asked. The ability of a person to convey answers to a given question has a close relationship with the knowledge that has been obtained by students and the ability to incorporate any knowledge that has been obtained in previous learning. The opinion above is reinforced by Sanjaya (2011), which states that the activity of submitting an answer shows someone's ability to think. This shows that the cognitive abilities of students are one of the factors that influence the level of oral activity of students in the class (Santrock, 2007).

The observation sheet instrument used to measure oral activity on the ALS-4 indicator shows conditions that remain constant meaning that there is no change in oral activity in terms of contributions within the group. The second cycle each indicator reaches a percentage of $56.25 \%, 57.82 \%$, $55.73 \%$ and $51.04 \%$. Different results shown by the results of a questionnaire filled out by students showed that there was a decrease in the level of the percentage of students' oral activity on the ALS-4 indicator. Some things that affect the effectiveness of group discussion are the number of group members, the topic or material of the discussion and the diversity of group members. The thing that distinguishes between discussion activities in the first cycle and discussions in the second cycle include: the topic of discussion, group members and the diversity of group members. The discussion topic given in the first cycle activity was animal-like protistas while the discussion topic given in the second cycle discussion was plant-like protistas.

\section{E. CONCLUSSION}

Based on the discussion and result show that the active learning system implementation with the Everyone is a Teacher Here $(E T H)$ method can enhance the oral activity of $\mathrm{X}-\mathrm{A}$ grade students in biology subjects at Dian Harapan Holland Village School, Manado. The enhance can be seen through the activities shown by sharing a fact in class, asking questions, giving answers and discussing.

The implementation of an active learning system with the Everyone is a Teacher Here (ETH) method can enhance the oral activity of class $X-A$ students in biology subjects at Dian Harapan Holland Village School, Manado by applying each stage of the method consisting of distributing index papers, providing 
opportunities for discussion, provide the opportunity to write questions, ask questions, provide answers to questions asked, provide rebuttal, exchange index cards and provide conclusions.

\section{BIBLIOGRAPHY}

Adhani, A. (2014). Pengaruh Strategi Pembelajaran Reciprocal Teaching dan Kemampuan Akademik Berbeda terhadap Keterampilan Berpikir Kritis, Aktivitas Lisan, dan Hasil Belajar Kognitif Biologi Siswa Kelas XI Semester Genap di SMA Kabupaten Takalar. DISERTASI dan TESIS Program Pascasarjana UM.

Arikunto, S. (2010). Penelitian Tindakan Kelas untuk Guru, Kepala Sekolah dan Pengawas. Yogyakarta: Aditya media.

Arikunto, S., Suhardjono, \& Supardi. (2012). Penelitian Tindakan Kelas. Jakarta: Bumi aksara.

Bada, S. O., \& Olusegun, S. (2015). Constructivism learning theory: A paradigm for teaching and learning. Journal of Research \& Method in Education, 5(6), 66-70.

Brame, C. (2016). Active Learning. Vanderbilt University Center for Teaching. Retrieved from https://cft.vanderbilt.edu/active-learning/.

Diedrich, B.P. (2015). Aktivitas Belajar Siswa. [online]: http://hamiddarmadi. blogspot.com/2015/04/aktivitas-belajar-siswa-ala-paul-b.html. Diakses pada tanggal 6 Juni 2017.

Edwards, S. (2015). Active Learning in the Middle Grades: This Article Offers Examples of Developing Students' Participation as a Central Tenet of Ideal Middle Level Education That Is Intellectually Active, Socially Active, and Physically Active. Middle School Journal, 46(5), 26-32.

Gimin, Kartikowati, Haryana. (2016). A Planning Design of Micro-Teaching Course (study from university of riau - indonesia). The 1 st International Conference on Economic Education and Entrepreneurship 2016. (203-216). Surabaya : Faculty of Economic Universitas Negeri Surabaya.

Hoekema, A. A. (2015). Manusia Ciptaan Menurut Gambar Allah. Surabaya: Momentum.

Hamalik, O. (2010). Proses Belajar Mengajar. Jakarta: Bumi aksara.

Kementrian Pendidikan dan Kebudayaan. (2014). Diambil dari https://kemdikbud.go.id/kemdikbud/dokumen/pdf

Kirkpatrick, D., \& Kirkpatrick, J. (2008). Evaluating Trainings Programs. San Francisco, California: Berrett-koehler.

Kosasih, E. (2016). Strategi Belajar dan Pembelajaran Implementasi Kurikulum 2013. Bandung: Yrama widya.

Leong, L. M., \& Ahmadi, S. M. (2017). An Analysis Of Factors Influencing Learners'english Speaking Skill.

Retrieved From http://ijreeonline.com/files/site1/user_files_68bcd6/sma1357-A-10-261 fefa0eb.pdf

Hossain, M. I. (2015). Teaching Productive Skills to the Students: A Secondary Level Scenario. (Doctoral dissertation, BRAC University).

Nugraha, R.M. (2019, December 5). Nadiem makarim plans to liberate college education system. Tempo. Retrieved from https://en.tempo.co/

Oktapratama, R., Chrismastianto, I. A. W., \& Hidayat, D. (2019). The Implementation of the Problem-Based Learning Method to Enhance Grade 7 Students'critical Thinking Skills In Learning Mathematics at SMP Holland Village Manado. JOHME: Journal of Holistic Mathematics Education, 3(1), 108-117.

Sanjaya, W. (2011). Strategi Pembelajaran Berorientasi Standar Proses Pendidikan. Jakarta: Kencana prenada media.

Santrock, J. W. (2007). Psikologi Pendidikan. Jakarta: Kencana.

Siberman, M. (2009). Pembelajaran Aktif. Kuala Lumpur: Institut Terjemahan Negara Malaysia Berhad. 
Siregar, E., \& Nara, H. (2010). Buku Ajar Teori Belajar dan Pembelajaran. Jakarta : UNJ.

Smith, J. B. (2014). The Good and Beautiful Community (Komunitas yang Baik dan Indah). Surabaya, Indonesia: Literatur Perkantas Jawa Timur.

Sumiati, \& Asra. (2008). Metode Pembelajaran. Bandung: Wacana prima.

Suprijono, A. (2009). Cooperative Learning: Teori 7 Aplikasi PAIKEM. Pustaka Pelajar.

Tampubolon, S. (2014). Penelitian Tindakan Kelas untuk Pengembangan Profesi Pendidik dan Keilmuan. Jakarta: Erlangga.

Trianto. (2011). Panduan Lengkap Penelitian Tindakan Kelas. Jakarta: Prestasi Pustakaraya. Warsono dan Hariyanto. (2012). Pembelajaran Aktif. Bandung: Remaja Rosdakarya.

Wibawanta, B., \& Hendra, J. (2017). Sebuah Tinjauan Sosiologi dari Perspektif Kristen. Tangerang: UPH press.

Winarso, W. (2016). Assessing The Readiness of Student Learning Activity and Learning Outcome. Jurnal Pencerahan, 10.

Wiriaatmadja, R. (2009). Metode Penelitian Tindakan Kelas. Bandung: Remaja Rosdakarya.

Yanti, P. D. K. (2017). Penerapan Metode Everyone Is A Teacher Here (ETH) untuk Meningkatkan Aktivitas dan Hasil Belajar dalam Pembelajaran IPS Kelas VIII C SMP NEGERI 2 SUKASADA Tahun Pelajaran 2016/2017. Jurnal Pendidikan Ekonomi Undiksha, 9(1), 177-187. 